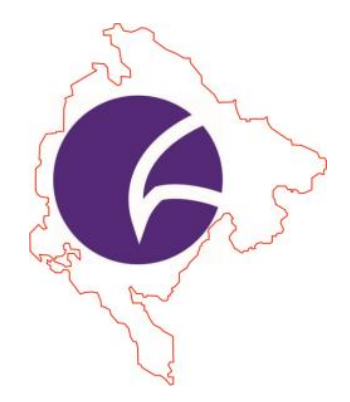

Montenegrin Journal of Economics

Vol. 16, No. 1 (2020), 169-182

\title{
Socialization of Organization Sustainable Development Based on the Principles of Corporate Social Responsibility
}

\author{
VLADIMER GLONTI ${ }^{1}$, VIKTOR TRYNCHUK ${ }^{2}$, INNA KHOVRAK ${ }^{3}$, \\ GANNA MOKHONKO ${ }^{4}$, MARINA SHKROBOT ${ }^{5}$ and LASHA MANVELIDZE 6
}

1 Professor, Dean of the Faculty of Economics and Business, Batumi Shota Rustaveli State University, Batumi, Georgia, e-mail: vladimer.ghlonti@bsu.edu.ge

2 Professor, Economics and Entrepreneurship Department, Kiev Institute of Business and Technology, Kiev, Ukraine, e-mail: victor_trinchuk@mail.ru

${ }^{3}$ Associate Professor, Accounting and Finance Department, Kremenchuk Mykhailo Ostrohradskyi National University, Kremenchuk, Ukraine, e-mail: inna.khovrak@gmail.com

${ }^{4}$ Associate Professor, Management Department, National Technical University of Ukraine "Igor Sikorsky Kiev Polytechnic Institute", Kiev, Ukraine, e-mail: mokhonkoa@gmail.com

${ }^{5}$ Associate Professor, Management Department, National Technical University of Ukraine “Igor Sikorsky Kiev Polytechnic Institute”, Kiev, Ukraine, e-mail: shkrobotmarina@ukr.net

6 Ph.D. Student, Department of Finance, Banking and Insurance, Batumi Shota Rustaveli State University, Batumi, Georgia, e-mail: lashamanvelidze@gmail.com

\section{ARTICLE INFO}

Received August 27, 2018

Revised from September 30 23, 2019

Accepted October 25, 2019

Available online March 15, 2020

JEL classification: M14; 015; 035

DOI: 10.14254/1800-5845/2020.16-1.11

Keywords:

Social responsibility, corporate social responsibility, sustainable development, business ethics, stakeholders.

\section{ABSTRACT}

The economic necessity becomes the orientation of the enterprise management system to ensure sustainable development, which will create a basis for increasing the economic strength of the enterprise, solving environmental and social problems. Increasing the social status of workers at enterprises, meeting the socially significant needs of the population are the priority areas of dynamic socioeconomic transformations. The socialization of the economy is largely determined by the satisfaction of the worker's needs, the completeness of their involvement in the modern process of transformation and the effectiveness of methods of human resources management. The purpose of this article is to substantiate the foundations of socialization of organization sustainable development based on the principles of corporate social responsibility (CSR). To confirm the hypothesis of the growth of the role of CSR, which is connected with the necessity of maximizing the positive influence on society through the implementation of the strategy of interaction between the organization and stakeholders. The possibility of introducing business ethics standards at each hierarchical level of management (top management, middle management, lower level management, and employees) are considered. It is proved, that the development of corporate social activities is becoming the most important managerial innovation, the service sector is characterized by a greater orientation towards achieving medium-term reputational effects while reducing the focus on short-term risk reduction, socially responsible company can successfully implement the principles of sustainable development in its activities, taking into account the requirement to harmonize social, economic and environmental priorities. 
Vladimer Glonti, Viktor Trynchuk, Inna Khovrak, Ganna Mokhonko, Marina Shkrobot and Lasha Manvelidze / Montenegrin Journal of Economics, Vol. 15, No. 1 (2020), 169-182

\section{INTRODUCTION}

The development of economic science in the recent decades has been accompanied by a change of paradigms of social development, the orientation of the economic policies of the developed countries for sustainable economic growth. The existing tendencies of development of the world community in the conditions of strengthening of uncertainty of the environment are characterized by the statement of a paradigm of sustainable development which is directed to satisfaction of the present generation needs, without doing at the same time harm to opportunities of future generations for satisfaction of their requirements. According to the doctrine of sustainable development a key task of progressive mankind is ensuring system coherence of social, economic and ecological priorities at all levels of economic system. It requires the solution of the whole complex of the problems connected with ensuring the harmonization of the goals of the functioning of the social, institutional, environmental, organizational and economic subsystems at the macro-, mezzo-, micro level and the tasks of sustainable development. Problems of social security of sustainable development of the organizations are important and so far sufficiently not solved, in particular, through a prism of CSR.

\section{METHODOLOGY}

The purpose of the article is to justify the principles of socialization of the organization's sustainable development based on the principles of CSR. Task of conceptualization of bases of CSR in ensuring sustainable development of the organization is achieved within a goal. Methods of research. For the purpose of achieving the goal, the following general scientific and specialized methods were used:

- critical analysis and comparison - for the determination of the social component of sustainable development,

- generalization and systematization - for highlighting the main activities and tasks of employees in the process of forming the company's business ethics;

- abstract-logical - for theoretical summarization and conclusion;

- graphical method - for visualization of the components of CSR, etc.

The methodological core of the research is a state of foreign and national economic thoughts on the analysis and audit issues. The information core of the research consists of regulations from international organizations and governments and analytical overviews from foreign audit associations and experts.

\section{THEORETICAL BACKGROUND}

Over the past twenty years, foreign and Ukrainian researchers have been developing a concept of social responsibility, as well as analyzing and summarizing the experience of socially responsible companies (Carroll, 1999; Post et al., 2002; Buleev et al. 2008). As business practice shows, questions of ecological and social responsibility are reflected in the majority of social reports of leading companies that represent special relevance at the present stage of development of public relations. Systematization of bases of sustainable development allows claiming that the social component is focused on the development of society, on the preservation of stability of public and cultural systems, on the reduction of a number of the conflicts in society. At the same time equitable distribution of the benefits between people becomes particularly important (reduction of a socalled Gini-index), pluralism of opinions, tolerance in the relations, preservation of the cultural capital and its variety. Undisputable influence on the development of social responsibility of business, formation of a relevant culture in society regarding the attitude to the person, the environment, has the level of education of the population (Koziuk et al., 2019), social heritage, historical memory 
Vladimer Glonti, Viktor Trynchuk, Inna Khovrak, Ganna Mokhonko, Marina Shkrobot and Lasha Manvelidze / Montenegrin Journal of Economics, Vol. 15, No. 1 (2020), 169-182

(Horyslavets et al., 2018), traditions and values (Trynchuk, 2011), which constitute socio-cultural capital. Quite detailed the question of socio-cultural capital, which emphasizes the role of social ties of personality and team in terms of the creation of barriers or competitive advantages were explored in the works. The study of these aspects on the example of insurance business we meet in the works of Klapkiv (2016) and Kaigorodova et al. (2018). Social orientation of sustainable development is based on respect of all human rights and fundamental freedoms, in particular the rights for development, openness, effective participation of the public in all spheres of social interaction. The social imperatives of sustainable development include:

- improving the living standards of the population through the eradication of poverty and disease;

- caring for children and the elderly;

- high level of quality of pre-school and school general education, education of children and adolescents;

- the struggle for peace, the prevention of a new world war and global conflicts;

- active assistance to the UN in peacekeeping and environmental activities.

The conceptual understanding of a social component of sustainable development is carried out on the basis of four categories of policy: human development; quality of life; the society founded on knowledge; institutional development of societ. With this in mind, the measurement of the social index of sustainable development is carried out using the appropriate indicators and parameters that characterize these categories of policy. With this in mind, the measurement of the social index of sustainable development is carried out using the appropriate indicators and parameters, which characterize these categories of policy. The methodology of social measurement of sustainable development at the level of the country is explained in work in more details. As for the measurement of the social component at the enterprise level, there are almost no generalized acceptable scientific and methodological provisions for estimating social parameters, which is caused, first of all, by insufficiently developed methodologies and ensuring the sustainable development of organizations. Considering the components of social measurement of sustainable development at the level of the enterprise, it should be noted that the structure of factors of influence on the socialization of processes of sustainable development has to be expanded taking into account such important element of efficient business as CSR. Bhattacharya, Sen and Korschub (2011, pp. 2930) indicate a fast-changing approach of companies to CSR:

- the concept of CSR is increasingly viewed as a business opportunity, not as an obligation;

- companies are beginning to see the role of other stakeholders such as investors, regulators, employees, nonprofits;

- the concept of CSR is being treated as a strategic, long-term approach, not as a single shot, as a one-off action in the short term.

Therefore, one may state that if a company wishes to be perceived as a reliable partner in a business, it should implement elements of this concept, and indeed this concept itself (Polinkevych, 2018, pp. 359). Also, companies should also remember that social responsibility may only be duly carried out and implemented in the organization on condition of a favorable approach of the management understanding the need for its development (Kucerova et al., 2016). CSR operates on the principle that firms are obliged to meet their responsibilities to their stakeholders and also shareholders (Goel and Ramanathan, 2014; Chersan et al., 2019; Cismas et al., 2019). Though CSR is a widely used concept both in the academic and corporate world, there is no clear and unbiased definition of this concept yet (Dahlsrud, 2006). Moreover, different CSR interpretations often confuse real-world practitioners. Carroll (1999) traces back the origin of the 'modern' CSR construct to the 1950s, but he claims that the concept has continuously evolved over subsequent decades. The European Commission characterizes CSR as a voluntary activity where companies integrate social and environmental concerns in their operations and interactions with their stakeholders (Green, 2001). Another definition explains CSR through religion. CSR, as a concept, 
Vladimer Glonti, Viktor Trynchuk, Inna Khovrak, Ganna Mokhonko, Marina Shkrobot and Lasha Manvelidze / Montenegrin Journal of Economics, Vol. 15, No. 1 (2020), 169-182

addresses the fact that profitability from business for some may come at the expense of others (Kraisornsuthasinee, 2012). Therefore companies are forced to maintain profitability and in the same time behave responsibly (Mohr et al., 2001) and this ethical behaviour should be based on the principles of honesty (Androniceanu, 2013), integrity and trustworthiness. CSR may be then defined as a concept whereby enterprises integrate social and environmental concerns in their operations and in their interaction with the stakeholders on a voluntary basis (Polinkevych, 2018, pp. 262). Through CSR, a company may improve its corporate performance by retaining talented employees, earn consumer and brand loyalty, reduce risk and build goodwill (Mullerat, 2010). Given these facts, the European Union continues to promote the CSR movement, although its implementation is diverse, and the movement is not well articulated in Europe, especially in some Mediterranean countries, e.g., in Greece (Donaldson and Fafaliou, 2003). The main factors which influence CSR activities in European countries are corporate features (size, sector), general (legal system, culture, nationality) and internal factors (civil systems). There are many definitions of CSR, this is a problem for methodology and understanding for science. It's necessary to realize and solve on the one way scientific and practice problems of stockholders:

- CSR encompasses the economic, legal, ethical and philanthropic expectations that society has of organisations at a given point in time (Carroll, 1979).

- $\quad$ CSR is a view of the corporation and its role in society that assumes a responsibility among links to pursue goals in addition to profit maximisation and responsibility of the stakeholders to hold the firm responsible for its actions (Werther and Chandler, 2011).

- $\quad$ CSR is business decision making linked to ethical values, compliance with legal requirements, and respect for people, communities and the environment around the world (Aaronson, 2003).

- Strategic CSR is the incorporation of a holistic CSR perspective within a firm s strategic planning and core operations so that the firm is managed in the interest of a broad set of stakeholders to achieve maximum economic and social value over the medium to long term (Werther and Chandler. 2011).

- Corporate citizenship is the extent to which businesses meet the economic, legal, ethical and discretionary responsibilities imposed on them by their stakeholders (Maignan et al., 1999).

- Conscious business refers to business galvanised by higher purposes that serve and align the interest of all major stakeholders (Mackey and Sisodia, 2011).

According to the definition of the Socially Responsible Business Forum of Ukraine, the social responsibility of business is the responsible attitude of any company to its product or service, to consumers, employees, partners; Active social position of the company, which consists in harmonious coexistence, interaction and constant dialogue with society, participation in solving acute social problems (Okhrimenko and Ivanova, 2015). Worldwide experience shows that a responsible attitude to the product and the consumer may be formed as initiative associations, unions that represent certain groups of companies, market sectors, and the initiative of the state through the mechanism of forming and developing community ombudsman. CSR in the most general interpretation (Kolot, 2014, pp. 70-71) is seen as a rational feedback of the organization to the system of contradictory expectations of interested parties (stakeholders) aimed at sustainable development of the company; it is the responsibility of those who make business decisions to those who are targeted by these decisions. In essence, CSR lity is a type of social commitment (mostly voluntary) implemented in corporate governance to employees, partners, the state, civil society institutions and society as a whole. CSR has turned into a well-grounded and business-oriented approach aimed at solving sustainable development problems (Kovalenko, 2015, p. 57). One of the most effective strategies of leadership in the market is the social responsibility of the business (Khovrak, 2017, p. 394). In the internal aspect, this manifests itself in the orientation of social responsibility for employees: training programs, collective insurance, corporate culture, etc. In the external aspect - on: business partners (reputation of the company) (Kaminski and Polinkevych, 2018); consumers (quality improvement programs, social advertising) (Polinkevych, 2017, pp. 299-304).; 
Vladimer Glonti, Viktor Trynchuk, Inna Khovrak, Ganna Mokhonko, Marina Shkrobot and Lasha Manvelidze / Montenegrin Journal of Economics, Vol. 15, No. 1 (2020), 169-182

society (provision of socially meaningful services, environmental protection programs, education and research, programs for cooperation with the authorities, support for sports (Bagautdinova et al., 2018), cultural and artistic events (Horyslavets et al., 2018), sponsorship (Polinkevych, 2017, pp.310-313). CSR is becoming a common world cultural norm, firms incorporate socially desired CSR actions into their business operations (Khoma et al. 2018). Concepts of social responsibility of business and socially oriented marketing are aimed at forming social competitive advantages of enterprises.

Socially responsible business (SRB) is based on observance of moral and ethical principles, respect for human rights, workers' rights and public environment, as well as on preserving the environment. Environmental aspects of social responsibility are reflected in the definition of the European Alliance (2019), according to which CSR is the concept of attracting social and environmental trends in business activities on the principles of voluntariness and interaction between all stakeholders (groups of influence). R. Kraplych (2005) interprets the SRB as a responsible attitude of any company to its product or service, to consumers, employees, partners; an active social position of a company, which is a harmonious existence and constant dialogue with society, participation in solving the acute social problems. The need to increase the level of the SRB all economic actors and institutions of society are caused by loss of stability of economic development, which requires searching for new factors and sources of economic growth; deepening of asymmetries between economic and social development that enhances economic and social danger; need to find new competitive advantages; ignoring of cultural and moral aspects in activities of economic entities (Kaminski and Polinkevych, 2018) and government structures; aggravation of environmental problems that can lead to disasters regional and national scale (Khovrak, 2016, pp. 197-198). Three main institutions as the state, the public (public organizations, research institutes and other think tanks), business circles represented by either companies or business community can be involved in the process of regulating and supporting the social responsibility of business (Figure 1).

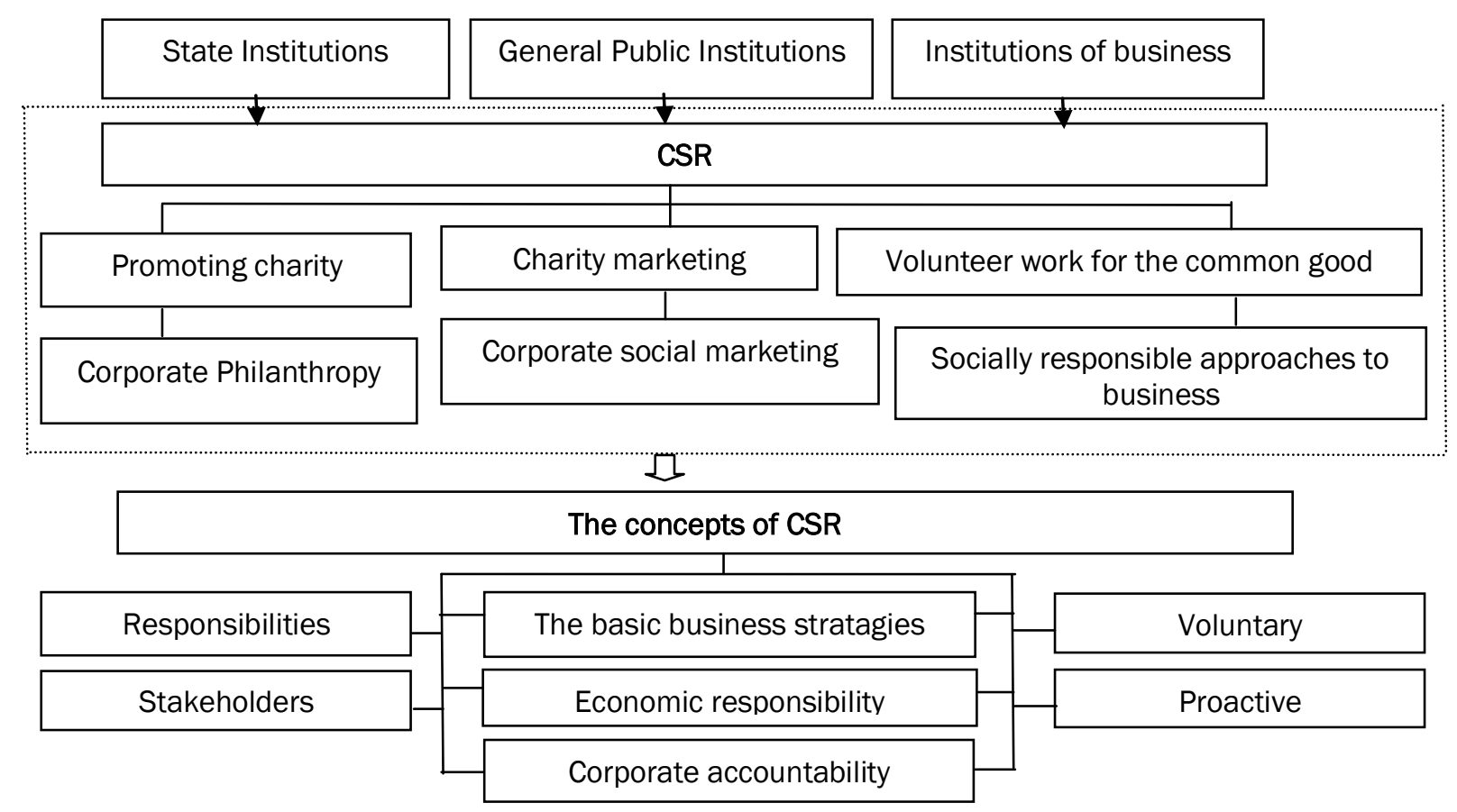

Figure 1. Components of CSR

Sources: developed by the authors on the basis of (European, 2019) 
Vladimer Glonti, Viktor Trynchuk, Inna Khovrak, Ganna Mokhonko, Marina Shkrobot and Lasha Manvelidze / Montenegrin Journal of Economics, Vol. 15, No. 1 (2020), 169-182

There is a wide variety of concepts and approaches to the SRB. The concepts of the SRB are differentiated depending on the national socio-economic and various types of stakeholders requiring action on these priorities. The main concepts of the SRB are given below. The concept of economic responsibility is that the SRB is understood as the economic responsibility of the firm for conducting business operations and supporting profitability. The concept of a basic business strategy. It provides that business can be only effective if the society in which it is operating is functioning well. The concept of duties argues that corporations should be judged not only on their economic successes but also non-economic criteria. To perform a good corporate role, the corporation must fulfil economic, legal, ethical, philanthropic, responsibilities. The concept of "stakeholders" provides that there are certain groups of interested persons (shareholders, workers, buyers, suppliers, the state, etc.) in the organization which influence the organization or whom the organization influences and who can be considered as such who confer certain responsibility on the organ ization. The concept of corporate accountability emphasizes, that the companies bear the responsibility for consequences of the actions and consequently should become more open before society, except (for the) responsibility before the interested sides. The concept of proactivity is a means of responding to changes in the sustainable development of society. Companies react reactive (reaction-based approach) or proactive (strategic approach). The company's election of one of the above concepts and its inclusion in its own development strategy allows us to begin the process of running a socially responsible business. The transition to a new standard business can be carried out by three possible options, which are arranged according to the degree of complexity of implementation. These are the implementation of individual projects related to the SRB, the implementation of the SRB program, which combines several projects and the implementation of the SRB strategy in all main processes of the company's activities.

Being based on international experience of social responsibility, the generalizing definition was offered by Kotler and Lee (2005) according to which social responsibility of business is a free choice of corporation for the benefit of the obligation to increase welfare of society through the corresponding approaches to business, and granting corporate resources. According to Kotler's classification (Post et.al., 2002), the socially responsible activities of the corporation can be reduced to six main initiatives (Figure 1).

Advance of charitable business - the company provides means, non-monetary and other corporate resources to draw attention of society to a certain social problem or to help to raise funds, to attract participants and volunteers. The company can act as individually, and with participation of the partner organizations. Charitable marketing - the company undertakes to make contributions or to deduct percent from sales volumes for charity. Of course, this initiative is calculated for a certain time, a product or charity. In this scenario, the company most often unites with the nonprofitable organization on mutually advantageous conditions so that to increase sales volumes of certain product and to attract financial resources for charity. Corporate social marketing - the company supports the development and / or conduct of campaigns for the modification of certain types of behavior (habits) in order to improve public health or safety, to promote the protection of the environment or the development of society. A special feature of this initiative is the focus on behavioral changes. This distinguishes it from the promotion of a socially useful case, which is focused on supporting measures to popularize, raise funds and attract volunteers. This initiative can be carried out by the company independently or with the invitation to partnership of a government agency or a non-profit organization. (The) corporate philanthropy - the company does donations of directly charitable organization or an action, most often in the form of monetary grants, gifts and/or goods or services. This initiative is the easiest to use. Volunteer work in the public interest - the company supports and encourages employees, retailers to help local social organizations and initiatives. It can be a program of one company or in partnership with a non-profit organization. Socially responsible approaches to doing business - the company at its own discretion introduces business practices and makes investments that contribute to the growth of well-being in society and the preservation of the environment. Initiatives can be implemented by one organization or in partnership with others. 
Vladimer Glonti, Viktor Trynchuk, Inna Khovrak, Ganna Mokhonko, Marina Shkrobot and Lasha Manvelidze / Montenegrin Journal of Economics, Vol. 15, No. 1 (2020), 169-182

\section{RESULTS}

Ethical problems in the company arise at collision of economic indicators and indicators of social responsibility when reasoning on receiving superfluous profits level social ethical standards of society. The ethical crisis of Ukrainian society is that the definition of ethics or unethical acts and actions of economic entities is not determined by law or any other way, but, first of all, is dictated by the need to carry out activities in conditions of uncertainty. Let's consider the possibility of introduction of standards of business ethics at each hierarchical level of management from the formulation of the main actions and tasks which have to be solved on it (Table 1).

Table 1. The main activities and tasks of employees in the process of forming the company's business ethics

\begin{tabular}{|c|c|}
\hline $\begin{array}{c}\text { Level of } \\
\text { management }\end{array}$ & Main tasks \\
\hline $\begin{array}{l}\text { Top Man- } \\
\text { agement }\end{array}$ & $\begin{array}{c}-\quad \text { Ethical communication is a priority; } \\
-\quad \text { Establish a good example of ethical behavior; } \\
-\quad \text { Adhere to commitments and promises; } \\
\text { - } \text { Provide transparency of information about the state of affairs and major events in } \\
\text { the company; } \\
\text { - Employees understand that top management is responsible for the violation of } \\
\text { ethics in the company. }\end{array}$ \\
\hline $\begin{array}{c}\text { Mid-level } \\
\text { management }\end{array}$ & $\begin{array}{c}-\quad \text { Ethical communication is a priority; } \\
-\quad \text { Establish a good example of ethical behavior; } \\
-\quad \text { Holds to commitments and promises; } \\
\text { - Employees understand that middle-level management is responsible for the viola- } \\
\text { tion of ethics in the company. }\end{array}$ \\
\hline $\begin{array}{c}\text { Management } \\
\text { of the lowest } \\
\text { level }\end{array}$ & $\begin{array}{c}-\quad \text { Ethical communication is a priority; } \\
-\quad \text { Establish a good example of ethical behavior; } \\
-\quad \text { Holds to commitments and promises; } \\
-\quad \text { Directs employees to adhere to organizational standards. }\end{array}$ \\
\hline Workers & $\begin{array}{c}\text { - They are guided by the rules of business ethics in the decision-making process; } \\
-\quad \text { Establish a good example of ethical behavior; } \\
-\quad \text { Awareness of the importance of business ethics; } \\
-\quad \text { Directs employees to adhere to organizational standards; } \\
\text { - Employees understand that they are responsible for the violation of ethics in the } \\
\text { company. }\end{array}$ \\
\hline
\end{tabular}

Sources: developed by the authors on the basis of (Johnson, 2003)

Thus, the certain actions connected with moral behavior in the company have a greater influence on results which are expected from the program of introduction of business ethics in the company. It is proved that at all levels of management in the companies' observance of obligations and promises, representation of an example of moral and responsible behavior and support of others in their desire to adhere to ethical standards, report to the company the greatest results. Holding conversations with employees about importance of business ethics reports smaller results. Respect for standards of the program of introduction of ethical behavior is more effective when employees in all organization act for development, but not just discussions, ethics. The research has shown that trainings concerning ethics are more useful in training of workers and employees of the lowest level of management, than top managers. It doesn't mean that the organizations have to refuse the programs of preparation intended for top levels of management. Perhaps, man- 
Vladimer Glonti, Viktor Trynchuk, Inna Khovrak, Ganna Mokhonko, Marina Shkrobot and Lasha Manvelidze / Montenegrin Journal of Economics, Vol. 15, No. 1 (2020), 169-182

agers of the highest levels develop ethical skills of a decision-making through own professional experience of advance upward on organizational hierarchy and therefore, training has various influence on employees of the lowest level of management who are not familiar with features of activity on the top level of management. Managers of the highest level of management can profit from the trainings helping to increase their awareness on details of unethical behavior, however the comprehensive programs of training directed to the strengthening of ethical skills of decisionmaking can be more useful to employees of the lowest level of management. In the leading Western companies, according to poll "Global Business Barometer" (Kulish, 2007), (UN, 2019), it is distinguished such features of the use of the principles of social responsibility in business practice (Table 2).

Table 2. Understanding of CR by representatives of Western companies

\begin{tabular}{|l|c|c|}
\hline \multicolumn{1}{|c|}{ Peculiarities of the perception of CSR } & $\begin{array}{c}\text { Number of respondents } \\
\text { who responded }\end{array}$ & $\%$ \\
\hline $\begin{array}{l}\text { Taking into account the interests of interested representatives of } \\
\text { the society when making business decisions }\end{array}$ & 426 & 38.4 \\
\hline $\begin{array}{l}\text { Maximization of profits and activities in the interests of share- } \\
\text { holders }\end{array}$ & 349 & 31.4 \\
\hline $\begin{array}{l}\text { Voluntary refusal of some incomes because of aspiration to make } \\
\text { "correct things" }\end{array}$ & 182 & 07.2 \\
\hline $\begin{array}{l}\text { Introduction of welfare through employment and payment of taxes } \\
\text { by the enterprise in time and in full }\end{array}$ & 80 & 6.6 \\
\hline $\begin{array}{l}\text { Support for initiatives that directly benefit the community, but are } \\
\text { not always profitable for shareholders }\end{array}$ & 73 & 100 \\
\hline Generally & 1110 & \\
\hline
\end{tabular}

Sources: compiled by the authors on the basis of (Kulish, 2007; UN, 2019)

The results of the conducted researches show that in the companies that are most consistent with the expectations of stakeholders, managers justify the need for CSR for business in terms of innovations aimed at the development of new market opportunities. At the same time, the development of corporate social activity becomes the most important administrative innovation. Domestic companies-respondents that took part in our research, interpret CSR as:

- output stage in the formation of the corporate strategy;

- an element of the overall business strategy of the company, allows you to manage non-financial risks;

- ideology defines the strategy of management of human resources of the organization.

Differences in the interpretation by business representatives of the relationship between CSR and the business development strategy do not violate the consistency in considering CSR as a component of the process of ensuring the competitiveness of the organization. The majority of respondents (83\%) consider CSR as a factor of the company's achievement of long-term competitive advantages. At the same time, $55 \%$ of them do not deny the strategic goal of determining the maintenance of the reputation in the medium term, as well as the short-term reduction of the risks of damage to the parties concerned (38\%). At this time, it should be noted that the purpose statement "obtaining long-term competitive advantages" practically doesn't depend on an accessory of the company to defined a branch cluster (the raw, overworking sectors or a services sector). At the same time, the sphere of services is characterized by a greater orientation toward achieving medium-term reputational effects while reducing the focus on reducing risks in the short term (Table 3). 
Vladimer Glonti, Viktor Trynchuk, Inna Khovrak, Ganna Mokhonko, Marina Shkrobot and Lasha Manvelidze / Montenegrin Journal of Economics, Vol. 15, No. 1 (2020), 169-182

Table 3. The objectives of the implementation of the strategy in the field of CSR, depending on the sectoral focus of enterprises, \% *

\begin{tabular}{|c|c|c|c|c|c|c|c|c|c|c|}
\hline \multirow[b]{2}{*}{$\begin{array}{l}\text { Objectives of implementing } \\
\text { the strategy }\end{array}$} & \multicolumn{10}{|c|}{ Industries } \\
\hline & 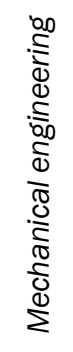 & क़े & $\bar{\pi}$ & $\begin{array}{l}\bar{d} \\
\frac{0}{\Phi} \\
\frac{d}{U}\end{array}$ & $\begin{array}{l}\frac{0}{\frac{1}{2}} \\
\frac{0}{0} \\
\frac{0}{0} \\
\frac{0}{0}\end{array}$ & 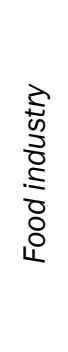 & 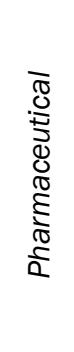 & 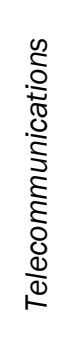 & 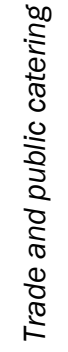 & $\stackrel{\substack{\infty \\
\frac{0}{5}}}{\infty}$ \\
\hline $\begin{array}{l}\text { Ensuring long-term competi- } \\
\text { tive advantages }\end{array}$ & 28 & 26 & 23 & 23 & 25 & 26 & 17 & 17 & 16 & 19 \\
\hline $\begin{array}{l}\text { Support of reputation in the } \\
\text { medium term }\end{array}$ & 24 & 25 & 24 & 27 & 29 & 29 & 32 & 34 & 33 & 29 \\
\hline $\begin{array}{l}\text { Reducing the risks of dam- } \\
\text { age to stakeholders in the } \\
\text { short term }\end{array}$ & 44 & 41 & 41 & 46 & 46 & 45 & 45 & 47 & 45 & 48 \\
\hline Other & 4 & 8 & 5 & 4 & 0 & 0 & 6 & 2 & 6 & 4 \\
\hline Total & 100 & 100 & & 100 & 100 & 100 & 100 & 100 & 100 & 100 \\
\hline
\end{tabular}

Note: Data are given as a percentage of the number of respondents who participated in the survey

CSR of the organization consists of its active and systematic participation in the economic, environmental and social development of the society, in cooperation with stakeholders. Social responsibility should be reflected in the mission of the organization by establishing an effective dialogue with all stakeholders, which allows them to better understand their needs and expectations. As it is indicated in the social report of CJSC Obolon (2019), social responsibility is a concept that encourages companies to take into account the interests of society by taking responsibility for the impact of the company's activities on consumers, stakeholders, employees, society and the environment in all aspects of its activities. According to the signed UN Global Compact in Ukraine, which is a voluntary initiative of socially responsible companies, CJSC Obolon provides information on CSR in the form of a social report. A social report is a document reflecting the company's policy, strategy and practice in the field of CSR. The social report of CJSC Obolon is prepared on the basis of the "Recommendations on reporting in the field of sustainable development" of the Global Reporting Initiative (GRI, version 3). It should be noted that the social report of company "Obolon" is the most productive in Ukraine - 110 completed GRI standard out of 121 possible. Among other things, the social report is evidence of the adoption of generally accepted standards of corporate governance.vThe social report of the organization, as a rule, includes a general characteristic of the organization; Responsibility before consumers, suppliers, personnel; Environmental responsibility; Responsible attitude of the organization to society. The social report of the company "Obolon" reflects the main components of the concept of sustainable development, namely:

- implementation of positive economic impact on the environment: providing jobs; implementation of innovative investments; the image of the national manufacturer; export of products; production of high-quality and competitive products;

- ensuring of ecological safety of (in) society: the introduction of ecological investments; optimization of the use of resources; reduction of the influence of the company by the environment; recycling and minimization of waste; 
- ensuring the development of staff and decent working conditions: the existence of high social standards and their compliance; decent wages; training and development of personnel; the standardized system of labor protection and personal safety; employment of disabled people;

- social investments: implementation of educational projects; help to socially unprotected segments of the population; assistance to the revival of spirituality and historical and cultural heritage; development of the sport.

The management of Obolon company understands both the stable development of the company and the environment in which it works as sustainable development. If in Obolon company the principles of sustainable development are reflected in the social report, then in world-famous corporation LLP "Henkel" key values and vision are recorded in four codes (LLP "Henkel", 2019):

- Code of corporate sustainable development, which reflects the basic principles of the company's interaction with stakeholders;

- The code of behavior which is drafted for the purpose of prevention of emergence of troubles at the workers working in other countries. This code establishes rules of business by the company in various countries, therefore, it isn't the steady document;

- The code of corporate design which reflects organizational and social values of the company on the creation of organizational structure; to establishing communication processes; orientation to innovations, etc.;

- Code of cooperation in the team and leadership, reflecting generalized approaches to setting goals for cooperation between managers and subordinates; Distribution of tasks; decision making; Evaluation of cooperation performance.

In business practice, codes are an appropriate form of institutionalizing the principles of CSR and reflect the company's core values to meet the social, economic and environmental expectations of stakeholders. So, the social reporting of leading companies reflects the socioenvironmental and economic priorities of the activity, which allow us to affirm the relationship between the concept of CSR and the concept of sustainable development. Taking into account the above, let us note the need to ensure the integration of the concepts of CSR and sustainable development. Realization of the principles of sustainable development in the socially responsible activity of the organization can be visually demonstrated in the form of the matrix "Priorities of sustainable development - stakeholders", which will reveal "bottlenecks" in the organization's strategic relationships with external and internal stakeholders (Table 4).

Table 4. Fragment of the matrix "Priorities of sustainable development - stakeholders"

\begin{tabular}{|c|c|c|c|c|c|c|c|c|}
\hline \multirow[b]{3}{*}{$\begin{array}{c}\text { Priorities of sustainable development of the } \\
\text { organization }\end{array}$} & \multicolumn{8}{|c|}{ Stakeholders } \\
\hline & \multicolumn{2}{|c|}{ Internal } & \multicolumn{6}{|c|}{ External } \\
\hline & 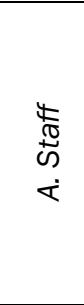 & 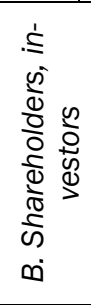 & 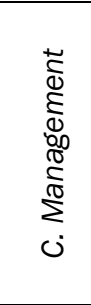 & $\begin{array}{l}\frac{\omega}{\omega} \\
\text { है } \\
\omega \\
\tilde{0} \\
0 \\
0 \\
0\end{array}$ & 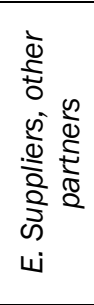 & 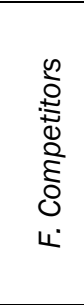 & 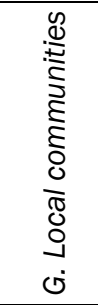 & 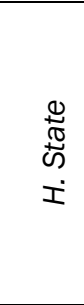 \\
\hline \multicolumn{9}{|l|}{ 1. Economic Priorities } \\
\hline $\begin{array}{l}\text { 1.1. The increase of the market value of the } \\
\text { enterprise, economic performance indica- } \\
\text { tors }\end{array}$ & 1.1.A & 1.1.B & 1.1.C & 1.1.D & 1.1.E & 1.1.F & 1.1.G & 1.1.H \\
\hline $\begin{array}{l}\text { 1.2. Obtaining long-term competitive ad- } \\
\text { vantage }\end{array}$ & 1.2.A & 1.2.B & 1.2.C & 1.2.D & 1.2.E & 1.2.F & 1.2.G & 1.2.H \\
\hline
\end{tabular}


Vladimer Glonti, Viktor Trynchuk, Inna Khovrak, Ganna Mokhonko, Marina Shkrobot and Lasha Manvelidze / Montenegrin Journal of Economics, Vol. 15, No. 1 (2020), 169-182

\begin{tabular}{|c|c|c|c|c|c|c|c|c|}
\hline $\begin{array}{l}\text { 1.3. Maintaining stable production and high } \\
\text { level of consumption }\end{array}$ & 1.3.A & 1.3.B & 1.3.C & 1.3.D & 1.3.E & 1.3.F & 1.3.G & 1.3.H \\
\hline $\begin{array}{l}\text { 1.4. Adherence to the principles of equality } \\
\text { and equity, taking into account social and } \\
\text { environmental priorities }\end{array}$ & 1.4.A & 1.4.B & 1.4.C & 1.4.D & 1.4.E & 1.4.F & 1.4.G & 1.4.H \\
\hline \multicolumn{9}{|l|}{ 2. Social priorities } \\
\hline 2.1. Satisfaction of consumers' needs. & 2.1. & 2.1.B & 2.1.C & 2.1.D & 2.1.E & 2.1.F & 2.1.G & 2.1.H \\
\hline $\begin{array}{l}\text { 2.2. Reducing the risk of harm to stake- } \\
\text { holders in the short term }\end{array}$ & 2.2.A & 2.2.B & 2.2.C & 2.2.D & 2.2.E & 2.2.F & 2.2.G & 2.2.H \\
\hline $\begin{array}{l}\text { 2.3. Raising the level and quality of life of } \\
\text { staff, consumers, stakeholders }\end{array}$ & 2.3.A & 2.3.B & 2.3.C & 2.3.D & 2.3.E & 2.3.F & 2.3.G & 2.3. $\mathrm{H}$ \\
\hline $\begin{array}{l}\text { 2.4. The increase of reputation, company's } \\
\text { image in the medium term }\end{array}$ & 2.4.A & 2.4.B & 2.4.C & 2.4.D & 2.4.E & 2.4.F & 2.4.G & 2.4.H \\
\hline \multicolumn{9}{|l|}{ 3. Environmental Priorities } \\
\hline $\begin{array}{l}\text { 3.1. Improve the environment for the com- } \\
\text { munity }\end{array}$ & 3.1.A & 3.1.B & 3.1.C & 3.1.D & 3.1.E & 3.1.F & 3.1.G & 3.1. $\mathrm{H}$ \\
\hline $\begin{array}{l}\text { 3.2. Reducing emissions of hazardous } \\
\text { waste into the atmosphere. }\end{array}$ & 3.2.A & 3.2.B & 3.2.C & 3.2.D & 3.2.E & 3.2.F & 3.2.G & 3.2.H \\
\hline 3.3. Rational use of natural resources. & 3.3.A & 3.3.B & 3.3.C & 3.3.D & 3.3.E & 3.3.F & 3.3.G & 3.3.H \\
\hline $\begin{array}{l}\text { 3.4. Optimization of expenses for environ- } \\
\text { mental protection. }\end{array}$ & 3.4.A & 3.4.B & 3.4.C & 3.4.D & 3.4.E & 3.4.F & 3.4.G & 3.4.H \\
\hline
\end{tabular}

Sources: systematised by the authors on the basis of (Blagov, 2006)

The basis for the development of this matrix is the approach to the formation of socially responsible leadership, proposed by the Russian scientist Blagov (2006) - the director of the Center for CSR of the Graduate School of Management of St. Petersburg State University. In his research, Blagov (2006) correlates the principles of ethical conduct of the organization with the expectations of stakeholders. Transforming these results into the conceptualization of the foundations of CSR in ensuring sustainable development, we made an assumption about the need to identify areas of mutual influence between different stakeholder groups and the organization's actions to achieve the priorities of its sustainable development. Analyzing the social reports of domestic companies, we found confirmation of our position and found the relevance of the study of the specifics of the formation of strategic interactions of the organization with external and internal stakeholders on the principles of sustainable development.

\section{DISCUSSION}

This integration allows us to conceptually substantiate the principles of the activity of a socially responsible organization in ensuring its sustainable development:

- The mission of the organization has to be formed taking into account social, economic, ecological expectations of interested parties. Vision and credo of the organization have to reflect the conceptual basis of sustainable development of the organization, proceeding from its behavior in the external environment and achievements of internal balance by its due to stability of organizational subsystems.

- The development strategy of the organization has to be directed to satisfaction of requirements and expectations of interested parties and, at the expense of it, to the achievement of the strategic social and economic objectives of activity at constant attention to prevention of pollution and preservation of the environment.

- The implementation of the organization's development strategy must have an innovative orientation. Ensuring of the sustainable development of a socially responsible organization can be carried out exclusively in the context of innovative transformations that form the basis for a balanced development of all subsystems of the organization, taking into account the interests of stakeholders. 
Vladimer Glonti, Viktor Trynchuk, Inna Khovrak, Ganna Mokhonko, Marina Shkrobot and Lasha Manvelidze / Montenegrin Journal of Economics, Vol. 15, No. 1 (2020), 169-182

- The organization must ensure the legal responsibility of the business. Responsible business conduct involves maintaining a permanent dialogue with interested population groups and observance of standard obligations stipulated by the laws of Ukraine.

- The organization must conduct an effective social policy that ensures decent working conditions for the staff; Acceptable level of wages; The necessary level of labor productivity, continuous professional training, professional development and training of all personnel; Reduction in staff turnover; Increase of social protection of employees; Health and safety of personnel; Improving the quality of life of staff.

- The organization's activities must comply with certain ethical norms and principles of philanthropy, which must be reflected in ethical codes of conduct; corporate culture; the implementation of active activities for charity, sponsorship; the implementation of social programs aimed at the development of cultural and moral values among various segments of the population.

Priorities of sustainable development should be taken into account by the organization's management when forming a corporate strategy, planning activities for designing strategically effective interactions of the organization with stakeholders and developing socially-oriented development programs.

\section{CONCLUSION}

The growing role of CSR is associated with the need to maximize the organization's positive impact on society through the implementation of the organization's interaction strategy with stakeholders. Imperatives of sustainable development of the world community make it necessary to update the conceptual content of CSR in terms of respecting the principles of sustainable development. This makes it necessary to consider the issues of CSR through the prism of the organization's strategic interaction with stakeholders, taking into account the compliance with the socioecological and economic challenges of society.

The economy of Ukraine requires the introduction of a mechanism to ensure sustainable socioeconomic growth. Thus, for the sustainable development and implementation of social management, it is advisable to strengthen the legal framework for social responsibility, to increase the responsibility of managers.

An important prerequisite for the formation and effective development of the institution of social responsibility is socio-economic policy, the state, as a regulating institute, must be developed. The social policy makes it possible to find a consensus in the society between different social groups, ensures a relative levelling in the income levels of the population and smooths disproportions in the reproduction process. When implementing social policy, it is necessary to take into account the fact that in the long run it always brings income, and in the short term there may be losses (unemployment benefits during periods of crisis, an increase in the number of people in need of social assistance).

The conducted researches allow claiming that socially responsible company can successfully introduce the principles of sustainable development in the activity taking into account implementation of the requirement of harmonization of social, economic and ecological priorities. Conceptualization of bases of CSR taking into account priorities of sustainable development promotes the corresponding systematization of bases of sustainable development of the organization in the conditions of challenges and threats.

Accordingly, in further research authors will be able to investigate the impact of the organization on different stakeholders, as well as analyze the Ukrainian and foreign experience of interaction with stakeholders. This will enable the development of mechanisms for effective interaction. In the future, such interaction will ensure the sustainable development of the regions and the country on the basis of social responsibility. 
Vladimer Glonti, Viktor Trynchuk, Inna Khovrak, Ganna Mokhonko, Marina Shkrobot and Lasha Manvelidze / Montenegrin Journal of Economics, Vol. 15, No. 1 (2020), 169-182

\section{REFERENCES}

Aaronson, S. (2003), "Corporate responsibility in lire global village: The British role model and the American laggard”, Business and Society Review, Vol. 108, No. 3, pp. 309-338.

Androniceanu, A. (2013), "Ethical values and the human resources behaviour in public management", Administration and Public Management Review, No. 20, pp. 49-61

Bhattacharya, C., Sen, S., Korschun, D. (2011), Leveraging corporate responsibility. The stakeholder route to maximizing business and social value, Cambridge University Press, Cambridge.

Blagov, J. (2006), "Genesis of Corporate Social Responsibility Concept", Bulletin of SaintPetersburg University, No. 2, Retrieved from https://cyberleninka.ru/article/n/geneziskontseptsii-korporativnoy-sotsialnoy-otvetstvennosti-2 (accessed 29 may 2019) (in Russian).

Buleev, I., Brjuhoveckaja, N., Chernyh, E. (2008), Social Responsibility for Business: Theory and Practice, IJeP NAN Ukrainy, DonUEP, Doneck (in Russian).

Carroll, A. (1999), "Corporate social responsibility: Evolution of definitional”, Business and Society, Vol. 38, No. 3, pp. 268-295. https://doi.org/10.1177/000765039903800303

Carroll. A. (1979), "A three-dimensional conceptual model of corporate performance", Academy of Management Review, Vol. 4, No. 4, pp. 497-505.

Chersan, I.-C., Chirila, V., Taran, A., Danilet, M. (2019), "Determinant factors of sustainable reporting in the uk - an analysis based on the reports from GRI'S sustainability disclosure database", Transformations in Business \& Economics, Vol. 18, No. 2A (47A), pp. 568-586.

Cismas, L.M., Miculescu, A., Negrut, L., Negrut, V., Otil, M.D., Vadasan, I. (2019), "Social capital, social responsibility, economic behavior and sustainable economic development - an analysis of Romania's situation", Transformations in Business \& Economics, Vol. 18, No 2A (47A), pp. 605-628.

Dahlsrud, A. (2006), "How Corporate Social Responsibility is defined: An analysis of 37 definitions", Corporate Social Responsibility and Environmental Management, Vol. 15, No. 1, pp. 1-13. https://doi.org/10.1002/csr.132

Donaldson, J., Fafaliou, I. (2003), "Business ethics, Corporate Social Responsibility and corporate governance: A review and summary critique", European Research Studies Journal, Vol. 6, No. 1-2, pp. 90-110.

European Alliance for CSR, Retrieved from https://www.businesseurope.eu/european-alliance-csr (accessed 2 may 2019).

Goel, M., Ramanathan, P.E. (2014), "Business ethics and Corporate Social Responsibility - Is there a dividing line?", Procedia Economics and Finance, Vol. 11, pp. 49-59, https://doi.org/ 10.1016/S2212-5671(14)00175-0

Green Paper Promoting a European framework for Corporate Social Responsibility (2001), Commission of the European Communities, Brussels.

Horyslavets, P., Plonka, M., Trynchuk, V. (2018), "Experience marketing and its tools in promoting the insurance services", Innovative Marketing, Vol.14, No.1, pp.41-48. doi: http://dx.doi.org/10.21511/im.14(1).2018.05

Johnson, H. (2003), "Does it pay to be good? Social responsibility and financial performance", Business Horizons, Vol. 46, No. 6, pp. 34-40. https://doi.org/10.1016/S0007-6813 (03)00086-7

Kaminski, R., Polinkevych, O. (2018), "Corporate image in behavioural marketing of business entities", Innovative Marketing, Vol. 14, No. 1, pp. 33-40.

http://dx.doi.org/10.21511/im.14(1).2018.04

Kaigorodova, G., Mustafina, A., Alyakina, D. (2018), "Directions of improving information system of insurance company", Journal of Physics: Conf. Series, Vol. 1015, Issue 4., Art. No. 042016. doi:10.1088/1742-6596/1015/4/042016

Klapkiv, Y. (2016), "A Strategy of institutional development in the market of insurance”, Scientific bulletin of Polissia, No. 4 (8/1), pp. 132-136.

Koziuk V., Dluhopolskyi, O., Hayda, Y., Klapkiv, Y. (2019), “Does educational quality drive ecological performance? Case of high and low developed countries", Global Journal of Science and Man- 
Vladimer Glonti, Viktor Trynchuk, Inna Khovrak, Ganna Mokhonko, Marina Shkrobot and Lasha Manvelidze / Montenegrin Journal of Economics, Vol. 15, No. 1 (2020), 169-182

agement, Vol. 5, Spec. Issue, pp. 22-32.

Khoma, I., Moroz, L., Horyslavets, P. (2018). Diagnostics of conflicts within the Business Social Responsibility Forming System. Journal of Competitiveness, Vol. 10(3), pp. 16-33. https://doi.org/10.7441/joc.2018.03.02

Khovrak, I. (2017) "Social responsibility as a strategy of market leadership of an enterprise", Public Management, No. 3 (39), pp.391-401. doi:10.4467/20843968ZP.16.030.7245 (in Poland).

Khovrak, I. (2016), "Current regulatory imperatives of social responsibility", The Scientific Papers of the Legislation Institute of the Verkhovna Rada of Ukraine, No. 1, pp. 197-203 (in Ukrainian).

Kolot, A. (2014), "Corporate social responsibility: modern philosophy, problems of acceptance", Ukrainian economy, No. 3 (628), pp. 70-82 (in Russian).

Kovalenko, E. (2015), "Evolution of business responsibility as a reflection of the social and economic processes of the macro level", Bulletin of the Odessa I.l. Mechnykov National University, Series: Economics, Vol. 20, No. 1/2, pp. 57-61 (in Ukrainian).

Kotler, P., Lee, N. (2005), Corporate Social Responsibility: Doing the Most Good for Your Company and Your Cause, Wiley, New York.

Kraisornsuthasinee, S. (2012), "CSR through the heart of the Bodhi tree", Social Responsibility Journal, Vol. 8, No. 2, pp. 186-198.

Kraplych, R. (2005), Corporate Social Responsibility for Ukrainian Business - Experience of the Ostrozky Foundation: A Guide for Business and Non-Profit Organizations, Rivne (in Ukrainian).

Kulish, A. (2007), Social responsibility of business in the banking sphere in questions and answers, Kiev (in Ukrainian).

Kucerova, R., Formankova, S., Prisazna, M. (2016), "Social Responsibility in high education institutions: evidence from public Universities in Czech Republic", Journal on Efficiency and Responsibility in Education and Science, Vol. 9, No. 4, pp. 88-96.

LLP "Henkel», Retrieved from https://www.henkel.ua/sustainability, accessed 2 may 2019, (in Ukrainian).

Mackey, J., Sisodia, R. (2014), Conscious capitalism: Liberating the heroic spirit of business. Boston, MA Harvard Business Review Press.

Maignan, I., Ferrell, O., Hull, G. (1999), “Corporate citizenship: Cultural antecedents and business benefits", Journal of the Academy of Marketing Science, No. 27(4), pp. 455-469.

Mohr, L., Webb, D., Harris, K. (2001), “Do consumers expect companies to be socially responsible? The impact of Corporate Social Responsibility on buying behaviour", The Journal of Consumer Affairs, Vol. 35, No. 1, pp. 45-72.

Mullerat, R. (2010), International Corporate Social Responsibility: The Role of Corporations in the Economic Order of the 21st Century, Kluwer Law International, Zuidpoolsingel.

Okhrymenko, O., Ivanova, T., (2015), Social responsibility, Kyiv: NTUU "KPl». Retrieved from http://ied.kpi.ua/wp-content/uploads/2015/10/Socialna-vidpovidalnist.pdf (in Ukrainian).

Post, J., Preston, L., Sachs, S. (2002), Redefining the corporation: Stakeholder management and organizational wealth, Stanford University Press, Stanford.

Polinkevych, O. (Ed.). (2017), Process and socially competent management of business systems development, Vezha-Druk, Lutsk, Retrieved from http://esnuir.eenu.edu.ua/bitstream 123456789/13749/1/Polinkevych\%20\%281\%29.pdf (in Ukrainian).

Polinkevych, O. (Ed.). (2018), Strategies and technologies innovative development corporations, Lutsk: Vezha-Druk. Retrieved from http://esnuir.eenu.edu.ua/bitstream/123456789/ 14618/2/Polinkevych_monograph2018.pdf (in Ukrainian).

Trynchuk, V. (2011), "Fire marks as a kind of outdoor advertising insurance company", Actual Problems in Economic, No. 8, pp. 50-59 (in Ukrainian).

UN Global Compact, Retrieved from http://www.globalcompact.org.ua (accessed 2 may 2019).

Werther, W., Chandler, I. (2011), Strategic corporate social responsibility: Stakeholders in a global environment, SAGE Publications Inc., Thousand Oaks, CA.

Zghurovskyj, M. (Ed.) (2010), Analysis of Sustainable Development - Global and Region Contexts: in 2 p., Kiev: NTUU "KPI» (in Ukrainian). 